\title{
Clinical Features and Treatment of 2019-nCov Pneumonia Patients in Wuhan: Report of A Couple Cases
}

\author{
Zhan Zhang ${ }^{1}$ (1) $\cdot$ Xiaochen $\mathrm{Li}^{1} \cdot$ Wei Zhang ${ }^{2} \cdot$ Zheng-Li Shi $^{2} \cdot$ Zhishui Zheng $^{1} \cdot$ Tao Wang $^{1}$
}

Received: 25 January 2020 / Accepted: 28 January 2020 / Published online: 7 February 2020

(c) Wuhan Institute of Virology, CAS 2020

\section{Dear Editor,}

Till January 20, 2020, the 2019-new coronavirus (2019$\mathrm{nCoV}$ ) has caused more than one hundred cases in Wuhan (WMHC 2020). During a retrospective study of recent pneumonia patients in our department, we found two patients who are likely being infected with the 2019-nCoV. During the hospitalization, those two patients were appropriately treated, and both were discharged within two weeks. Thus, we are reporting the clinical features and treatment regiment, and hope the information and experience can be shared.

The two patients were a couple. The male was 38 years old, and was admitted to the hospital due to fever for one week and dyspnea for one day on Dec. 27, 2019. On admission, he had slight cough of a little green viscous sputum. He had been treated with normal anti-infective therapy in another hospital for 3 days, but did not respond it. After then, he visited our department. The radiography of the chest at the OPD suggested the right lung infection.

He was previously healthy, and had a history of allergy to heartleaf houttuynia herb (a traditional Chinese medicine). Physical examination (PE) on admission: T: $37.4{ }^{\circ} \mathrm{C}$; P: 95 bpm; R: 20 bpm; and BP: 129/73 mmHg. The breath sounds of both lungs were coarse, and no dry or moist rales were auscultated. The heart and abdomen were unremarkable. Routine urine test: urine glucose: 1+; urine specific gravity: 1.03 ; protein: $1+$; and the others were

\section{Zhan Zhang}

doctorzhang2003@163.com

1 Department of Respiratory Disease and Intensive Care, Renmin Hospital of Wuhan University, Wuhan 430060, China

2 CAS Key Laboratory of Special Pathogens, Wuhan Institute of Virology, Center for Biosafety Mega-Science, Chinese Academy of Sciences, Wuhan 430071, China within the normal ranges. Routine stool test: occult blood (chemical method): weakly positive. The creatine kinase was within the normal range; lactate dehydrogenase: 279 $\mathrm{U} / \mathrm{L} \uparrow$; and procalcitonin was within the normal range.

To figure out the potential pathogen of his infection, a panel of extra laboratory tests was performed, and the results are shown in Table 1. Through those tests, all clinically frequent pathogens are excluded.

During the hospitalization, the CT scans of lungs and the dynamics of immune responses were closely monitored. Summary reports of serial CT scans and serial blood tests of the male patient are shown in Fig. 1 and Table 2.

After admission, according to our clinical experience, the patient was given methylprednisolone $40 \mathrm{mg}$ iv gtt for once, and then the fever subsided. The patient was given human gamma globulin $10 \mathrm{~g}$ iv gtt qd for five successive days, and then the dose was changed to $5 \mathrm{~g}$. Considering the cause was unknown, we also used drugs to treat atypical pathogens, including moxifloxacin for mycoplasma and chlamydia, and oseltamivir and abidol hydrochloride for influenza A virus; meanwhile, the patient was given Chinese patent medicine Tanreqing iv gtt for adjunctive therapy. On Jan 10, 2020, the male patient was re-examined for all inflammatory indices and all showed normal, and he was discharged from hospital on the same day.

The female patient was 38 years old and was admitted due to fever, cough, and vomiting for one day on Dec 30, 2019. On admission, she had no dyspnea, no chest distress, no expectoration, no pharyngalgia, no nasal discharge, nor nasal obstruction. She was previously healthy, and had no history of allergy to food or drug. PE on admission: T: $38.5{ }^{\circ} \mathrm{C}$; P: 128 bpm; R: 22 bpm; and BP: 107/68 mmHg. The breath sounds of both lungs were coarse, and no dry or moist rales were auscultated. The heart and abdomen were unremarkable. The urine and stool examination results were unremarkable. The creatine kinas, lactate dehydrogenase, and procalcitonin were all within the normal ranges. She was examined for the same panel of known pathogens as her husband did, and all showed negative. 
Table 1 Laboratory tests for known pathogens of the male patient.

\begin{tabular}{|c|c|c|c|c|c|c|c|}
\hline $\begin{array}{l}\text { Throat swab, } \\
\text { antigen detection }\end{array}$ & Result & $\begin{array}{l}\text { Throat swab, nucleic } \\
\text { acid detection }\end{array}$ & Result & $\begin{array}{l}\text { Serum, antibody } \\
\text { detection (IgM) }\end{array}$ & Result & $\begin{array}{l}\text { Serum, nucleic } \\
\text { acid detection }\end{array}$ & Result \\
\hline Influenza A virus & Negative & $\begin{array}{l}\text { Influenza A virus, } \\
\text { H7-RNA }\end{array}$ & Negative & $\begin{array}{l}\text { Legionella } \\
\text { pneumophila serum } \\
\text { type } 1\end{array}$ & Negative & $\begin{array}{l}\text { Cytomegalovirus, } \\
\text { DNA }\end{array}$ & $\begin{array}{l}<5.00 \mathrm{E}+2 \\
\text { Minimal detection } \\
\text { limit } 5.00 \mathrm{E}+02\end{array}$ \\
\hline Influenza $B$ virus & Negative & $\begin{array}{l}\text { Influenza A virus, } \\
\text { N9-RNA }\end{array}$ & Negative & $\begin{array}{l}\text { Mycoplasma } \\
\text { pneumoniae }\end{array}$ & Negative & EB virus, DNA & $\begin{array}{l}<5.00 \mathrm{E}+3 \\
\text { Minimal detection } \\
\text { limit } 5.00 \mathrm{E}+03\end{array}$ \\
\hline Adenovirus & Negative & $\begin{array}{l}\text { Influenza A virus, } \\
\text { RNA }\end{array}$ & Negative & Q fever Rickettsia & Negative & & \\
\hline $\begin{array}{l}\text { Respiratory } \\
\text { syncytial virus }\end{array}$ & Negative & $\begin{array}{l}\text { Influenza A virus } \\
\text { H1N1, RNA }\end{array}$ & Negative & $\begin{array}{l}\text { Chlamydia } \\
\text { pneumonia }\end{array}$ & Negative & & \\
\hline $\begin{array}{l}\text { Parainfluenza } \\
\text { virus (type } 1 \text { ) }\end{array}$ & Negative & $\begin{array}{c}\text { Influenza A virus } \\
\text { H3N2, RNA }\end{array}$ & Negative & Adenovirus & Negative & & \\
\hline $\begin{array}{l}\text { Parainfluenza } \\
\text { virus (type 2) }\end{array}$ & Negative & $\begin{array}{l}\text { Influenza B virus, } \\
\text { RNA }\end{array}$ & Negative & $\begin{array}{l}\text { Respiratory syncytial } \\
\text { virus }\end{array}$ & Negative & & \\
\hline \multirow[t]{9}{*}{$\begin{array}{l}\text { Parainfluenza } \\
\text { virus (type } 3 \text { ) }\end{array}$} & Negative & $\begin{array}{l}\text { Parainfluenza virus, } \\
\text { RNA }\end{array}$ & Negative & Influenza A virus & Negative & & \\
\hline & & $\begin{array}{l}\text { Respiratory } \\
\text { syncytial virus, } \\
\text { RNA }\end{array}$ & Negative & Influenza B virus & Negative & & \\
\hline & & $\begin{array}{l}\text { Metapneumovirus, } \\
\text { RNA }\end{array}$ & Negative & $\begin{array}{l}\text { Parainfluenza virus } \\
\text { type } 1 / 2 / 3\end{array}$ & Negative & & \\
\hline & & $\begin{array}{l}\text { SARS coronavirus, } \\
\text { RNA }\end{array}$ & Negative & & & & \\
\hline & & Rhinovirus, RNA & Negative & & & & \\
\hline & & Adenovirus, DNA & Negative & & & & \\
\hline & & $\begin{array}{l}\text { Bocaparvovirus, } \\
\text { DNA }\end{array}$ & Negative & & & & \\
\hline & & $\begin{array}{l}\text { Pneumonia } \\
\text { mycoplasma, } \\
\text { DNA }\end{array}$ & Negative & & & & \\
\hline & & $\begin{array}{l}\text { Pneumonia } \\
\text { chlamydia, DNA }\end{array}$ & Negative & & & & \\
\hline
\end{tabular}

During her hospitalization, the CT scan of lungs and the dynamics of immune responses were also closely monitored. Summary reports of serial CT scans and serial blood tests of the female patient are shown in Fig. 2 and Table 3.

After admission, according to clinical experience, the patient was given methylprednisolone $40 \mathrm{mg}$ iv gtt for five days, then the patient was given human gamma globulin $10 \mathrm{~g}$ iv gtt qd for seven successive days, and then the dose was changed to $5 \mathrm{~g}$. The other drugs were the same as her husband. We also used drugs to treat atypical pathogens, including moxifloxacin for mycoplasma and chlamydia, and oseltamivir and abidol hydrochloride for influenza A virus; meanwhile, the patient was given Chinese patent medicine Tanreqing iv gtt for adjunctive therapy. On Jan 10, 2020, the female patient was re-examined for all inflammatory indexes and all showed normal, and he was discharged from hospital on the same day.

After the news press release of China CDC on January 9, 2020 (China CDC 2020), and the confirmation of the 2019-nCoV on January 12 from WHO (WHO 2020), we tested the serum samples of those two couple patients with coronavirus antibodies provided by Prof. Zheng-Li Shi (Wuhan Institute of Virology, Chinese Academy of Sciences) (Wang et al. 2018). The tests results are shown in Table 4, which indicate that the couple patients were both positive for coronavirus infections.

In this couple, the clinical manifestations were moderate to ardent fever, and decrease in white blood cells and lymphocytes; CT findings of the chest were patchy shadows or ground-glass shadows in multiple segments and lobes; they did not respond to 3-day normative anti- 
Fig. 1 CT scans of the chest of the male patient.

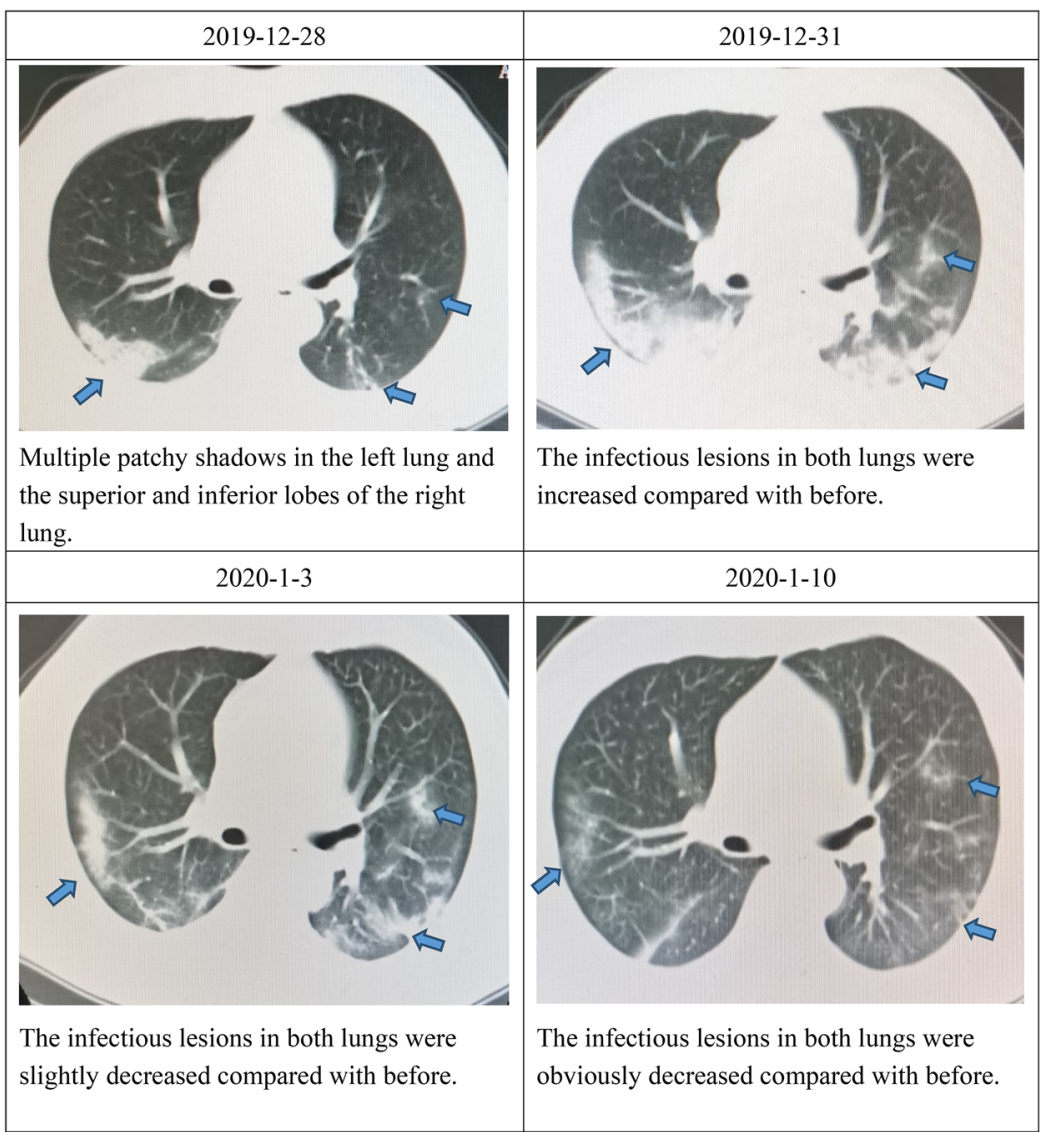

infective therapy in another hospital; and the occurrence was clustering. The above mentioned indicators meet the clinical diagnostic standards for unexplained pneumonia issued in China (National Health Commission of the People's Republic of China 2007). But the clinical manifestations in this couple were not exactly the same. On admission, beside fever, the male was predominately manifested by dyspnea and only had mild abnormality in routine urine and stool test results, while the female had obvious gastrointestinal symptoms such as vomiting and diarrhea. These suggest this virus may be present in urine and stools, but we did not run pathogen isolation and detection, and it is only presumption. As for why the male had only abnormality in urine and stools rather than gastrointestinal symptoms, while the female had no abnormality in urine or stools but had gastrointestinal symptoms on the contrary, we have no definite explanation. Before the onset, the couple went to a restaurant one stop away from the Huanan Seafood Wholesale Market to eat frozen seafood. Maybe they get sick after being exposed to the same pathogen. The male developed symptoms first and had more severe clinical symptoms, which may be related to his immunity was better than the female. After the first exposure to the virus, patients with better immunity have stronger body reactions.

Innate immune cells play a vital role in effective host responses to various pathogens. Neutrophils and monocytes-macrophages are the major innate immune cells that coordinate innate immunity against viral lung infections. Respiratory viruses can inhibit the innate immune response, and consequently obtain effective opportunities for virus replication and infection. The affected innate immune response also affects subsequent adaptive immune responses; so, viral innate immune evasion often disrupts the complete protective immunity (Kikkert 2020). Therefore, initially, of the two patients, the female had normal neutrophilic granulocytes initially, and both had normal monocytes.

The levels of CD3, CD4, CD8, CD19, and CD16 + 56 cells were all decreased in both patients. It is speculated that the number of immune cells in the blood decreased due to a large number of them were lost or exuded to the 
Table 2 A summary report of serial blood tests of the male patient, and the chief complains of the patient.

\begin{tabular}{|c|c|c|c|c|c|}
\hline Laboratory indices & Dec. 28, 2019 & Dec. 31,2019 & Jan. 3, 2020 & Jan. 10, 2020 & $\begin{array}{l}\text { Normal } \\
\text { range }\end{array}$ \\
\hline $\begin{array}{l}\text { Total white cells } \\
\left(\times 10^{9} / \mathrm{L}\right)\end{array}$ & $2.11 \downarrow$ & $2.88 \downarrow$ & $2.87 \downarrow$ & 4.10 & $3.5-9.5$ \\
\hline Neutrophils $\left(\times 10^{9} / \mathrm{L}\right)$ & $0.99 \downarrow$ & $2.15 \downarrow$ & $1.50 \downarrow$ & 1.93 & $1.8-6.3$ \\
\hline Lymphocytes $\left(\times 10^{9} / \mathrm{L}\right)$ & $0.89 \downarrow$ & $0.49 \downarrow$ & $0.92 \downarrow$ & 1.57 & $1.1-3.2$ \\
\hline Monocytes $\left(\times 10^{9} / \mathrm{L}\right)$ & 0.23 & 0.24 & 0.42 & 0.50 & $0.1-0.6$ \\
\hline Eosinophils $\left(\times 10^{9} / \mathrm{L}\right)$ & 0 & 0 & 0.02 & 0.07 & $0.02-0.52$ \\
\hline $\begin{array}{l}\text { C-reactive protein } \\
(\mathrm{CRP})(\mathrm{mg} / \mathrm{L})\end{array}$ & $35.43 \uparrow$ & $121 \uparrow$ & $41.17 \uparrow$ & $<0.5$ & $0-10$ \\
\hline $\begin{array}{l}\text { Serum amyloid A } \\
\text { (SAA) }(\mathrm{mg} / \mathrm{L})\end{array}$ & $82.77 \uparrow$ & $153 \uparrow$ & $52.62 \uparrow$ & $<5.00$ & $<10$ \\
\hline $\mathrm{CD} 3(/ \mu \mathrm{L})$ & & $273 \downarrow$ & & & $723-2737$ \\
\hline $\mathrm{CD} 4(/ \mu \mathrm{L})$ & & $145 \downarrow$ & & & $404-1612$ \\
\hline $\mathrm{CD} 8(/ \mu \mathrm{L})$ & & $114 \downarrow$ & & & $220-1129$ \\
\hline CD19 $(/ \mu \mathrm{L})$ & & $52 \downarrow$ & & & $80-616$ \\
\hline $\mathrm{CD} 16+56(/ \mu \mathrm{L})$ & & $104 \downarrow$ & & & $84-724$ \\
\hline $\operatorname{IgG}(\mathrm{g} / \mathrm{L})$ & & $6.26 \downarrow$ & & & $8-16$ \\
\hline $\operatorname{IgM}(\mathrm{g} / \mathrm{L})$ & & Normal & & & $0.4-3.45$ \\
\hline $\operatorname{IgA}(\mathrm{g} / \mathrm{L})$ & & Normal & & & $0.76-3.9$ \\
\hline $\operatorname{IgE}(\mathrm{g} / \mathrm{L})$ & & Normal & & & $<100$ \\
\hline C3 (g/L) & & Normal & & & $0.81-1.6$ \\
\hline C4 (g/L) & & Normal & & & $0.1-0.4$ \\
\hline $\begin{array}{l}\text { Chief complaints } \\
\text { of the patient }\end{array}$ & $\begin{array}{l}\text { The fever subsided, but } \\
\text { the patient still had } \\
\text { cough, chest distress, } \\
\text { and dyspnea }\end{array}$ & $\begin{array}{l}\text { The patient had no fever, } \\
\text { and the cough, chest } \\
\text { distress, and dyspnea } \\
\text { were slightly improved }\end{array}$ & $\begin{array}{l}\text { The symptoms } \\
\text { were improved }\end{array}$ & $\begin{array}{l}\text { The patient complained of } \\
\text { no discomforts }\end{array}$ & \\
\hline
\end{tabular}

infectious site to participate in the body's defense response. On January 5, 2020, the female' conditions were improved, but the CD3, CD4, and CD8 cells declined further. Perhaps the female patient recalled more immune cells to participate in the antiviral process in her body. Our observations show that the number of CD3, CD4, and CD8 cells cannot predict disease progression. In this study, the male had a more severe decrease in immune cells and more severe conditions than the female. In addition, after comparing our other similar cases, we found that the lower the number of primary immune cells, the more severe the conditions, which is consistent with previous observations (Huang et al. 2004).

It is known that in the resting state NK cells are CD56 + CD16-. After stimulation, they activate and transform into cytotoxic CD56 + CD16 + NK cells and participate in the antiviral immunity (Seillet et al. 2016).
After the female's condition improvement, the number of CD19 + and CD16 + 56 + cells increased, and this may suggest that the number of CD19 + and CD16 + 56+ cells can be used as an indicator of the patient's disease status.

From a previous study on the dynamic changes of peripheral blood immune cells in some 2003 SARS cases reported by Dr. Jianping Zhang et al. from Beijing Ditan Hospital, it was shown that during the onset of SARS patients, B cells showed a continuous increase, while NK cells showed a slow and continuous decline, which was statistically significant (Zhang et al. 2003). However, our female patient is not consistent with this observation. May it suggest that the 2019-nCoV induce slight different immune response from the SARS-CoV? To answer this, it requires more samples and further comprehensive studies. 
Fig. 2 CT scans of the chest of the female patient.

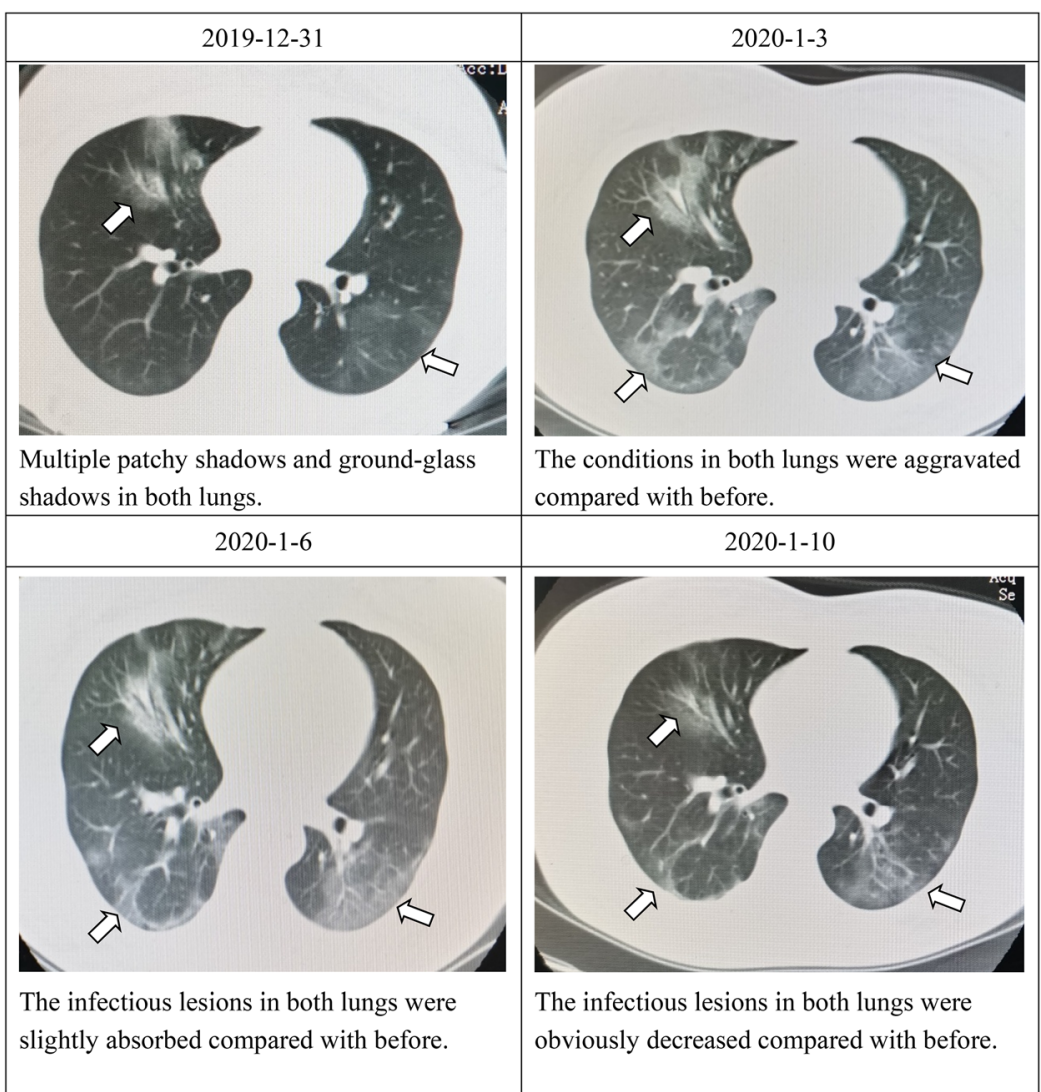

When the symptoms in the male were improved on January 3, 2020, the chest imaging manifestations progressed a little compared with before on the contrary. This condition was previously reported in severe Legionella pneumonia. The condition change was manifested mainly by clinical symptoms, while the imaging manifestations may be related to the increased exudation and strengthened responsiveness. But it is interesting that the patient's condition was improved but CRP and SAA were also increased, which has not attracted attentions in the past. It was the same in the female. On January 5, 2020, the patient's condition was improved, and the image showed the lesions were slightly absorbed when compared with before, while CRP and SAA were also increased significantly. This aspect is worthy of further observation and research.

The treatment of these two patients was successful, and they both were discharged from the hospital within 2 weeks. As for experience of medication, we used large doses of gamma globulin, and hormone at the beginning of the disease. But the duration of hormone was different for different patients. After using $40 \mathrm{mg}$ once, the drug was no longer used for the male, while the female used it for a longer time, mainly according to the clinical symptoms and changes of chest imaging findings. Other treatments were antibacterial drugs, drugs for atypical pathogens such as mycoplasma and chlamydia, oseltamivir and abidol hydrochloride for viruses, and Chinese herbal medicine Tanreqing.

In general, even in patients with the same viral infection, the clinical manifestations can be different; the severity of the condition may be related to the number of immune cells; CRP and SAA may not only be related to the severity of the infection, but may also indicate the outcome of the condition; and human blood gamma globulin and hormone appeared to play roles in the treatment of these two patients. 
Table 3 A summary report of serial blood tests of the female patient, and the chief complains of the patient.

\begin{tabular}{|c|c|c|c|c|c|c|}
\hline Laboratory indices & Dec. 31, 2019 & Jan. 3, 2020 & Jan. 5, 2020 & Jan. 8, 2020 & Jan. 10, 2020 & $\begin{array}{l}\text { Normal } \\
\text { range }\end{array}$ \\
\hline Total white cells $\left(\times 10^{9} / \mathrm{L}\right)$ & $2.83 \downarrow$ & $2.41 \downarrow$ & $1.58 \downarrow$ & 6.29 & 7.54 & $3.5-9.5$ \\
\hline Neutrophils $\left(\times 10^{9} / \mathrm{L}\right)$ & 2.07 & $1.47 \downarrow$ & $0.89 \downarrow$ & 4.10 & 6.06 & $1.8-6.3$ \\
\hline Lymphocytes $\left(\times 10^{9} / \mathrm{L}\right)$ & $0.55 \downarrow$ & $0.75 \downarrow$ & $0.60 \downarrow$ & 1.79 & 1.07 & $1.1-3.2$ \\
\hline Monocytes $\left(\times 10^{9} / \mathrm{L}\right)$ & 0.21 & 0.19 & $0.09 \downarrow$ & 0.39 & 0.40 & $0.1-0.6$ \\
\hline Eosinophils $\left(\times 10^{9} / \mathrm{L}\right)$ & $0 \downarrow$ & $0 \downarrow$ & $0 \downarrow$ & $0 \downarrow$ & $0 \downarrow$ & $0.02-0.52$ \\
\hline $\begin{array}{l}\text { C-reactive protein }(\mathrm{CRP}) \\
(\mathrm{mg} / \mathrm{L})\end{array}$ & $19.94 \uparrow$ & $10.50 \uparrow$ & $25.4 \uparrow$ & $<0.5$ & $<0.5$ & $0-10$ \\
\hline $\begin{array}{l}\text { Serum amyloid A } \\
(\mathrm{SAA})(\mathrm{mg} / \mathrm{L})\end{array}$ & $47.54 \uparrow$ & $77.24 \uparrow$ & $>300 \uparrow$ & 20.52 & $<5.00$ & $<10$ \\
\hline CD3 $(/ \mu \mathrm{L})$ & $383 \downarrow$ & & $290 \downarrow$ & & 1403 & $723-2737$ \\
\hline $\mathrm{CD} 4(/ \mu \mathrm{L})$ & $176 \downarrow$ & & $122 \downarrow$ & & 826 & $404-1612$ \\
\hline $\mathrm{CD} 8(/ \mu \mathrm{L})$ & $182 \downarrow$ & & $142 \downarrow$ & & 537 & $220-1129$ \\
\hline CD19 $(/ \mu \mathrm{L})$ & $41 \downarrow$ & & $79 \downarrow$ & & 326 & $80-616$ \\
\hline $\mathrm{CD} 16+56(/ \mu \mathrm{L})$ & $23 \downarrow$ & & $42 \downarrow$ & & $26 \downarrow$ & $84-724$ \\
\hline $\operatorname{IgG}(\mathrm{g} / \mathrm{L})$ & Normal & & Normal & & Normal & $8-16$ \\
\hline $\operatorname{IgM}(\mathrm{g} / \mathrm{L})$ & Normal & & Normal & & Normal & $0.4-3.45$ \\
\hline $\operatorname{Ig} \mathrm{A}(\mathrm{g} / \mathrm{L})$ & Normal & & Normal & & Normal & $0.76-3.9$ \\
\hline $\operatorname{IgE}(\mathrm{g} / \mathrm{L})$ & Normal & & Normal & & Normal & $<100$ \\
\hline C3 (g/L) & Normal & & Normal & & $0.728 \downarrow$ & $0.81-1.6$ \\
\hline C4 (g/L) & Normal & & Normal & & $0.063 \downarrow$ & $0.1-0.4$ \\
\hline $\begin{array}{l}\text { Chief complaints } \\
\text { of the patient }\end{array}$ & $\begin{array}{l}\text { Fever, cough, } \\
\text { and vomiting }\end{array}$ & $\begin{array}{l}\text { Still fever, } \\
\text { cough, and } \\
\text { diarrhea } \\
\text { (passing watery } \\
\text { stools) }\end{array}$ & $\begin{array}{l}\text { The fever subsided, } \\
\text { the diarrhea } \\
\text { disappeared, and } \\
\text { the cough lasted }\end{array}$ & $\begin{array}{l}\text { The fever and } \\
\text { diarrhea } \\
\text { disappeared, and } \\
\text { the cough was } \\
\text { improved }\end{array}$ & $\begin{array}{l}\text { The patient } \\
\text { complained } \\
\text { of no } \\
\text { discomforts }\end{array}$ & \\
\hline
\end{tabular}

Table 4 Coronavirus $\mathrm{IgM}$ and $\mathrm{IgG}$ detection in patients

\begin{tabular}{lllll}
\hline & $\operatorname{IgM}$ & Cut-off value & $\operatorname{IgG}$ & Cut-off value \\
\hline Male patient & 0.530 & $\geq 0.2$ & 1.770 & $\geq 0.15$ \\
Female patient & 1.645 & $\geq 0.2$ & 1.433 & $\geq 0.15$ \\
\hline
\end{tabular}

Acknowledgements This work was supported by the strategic priority research program of the Chinese academy of sciences (XDB29010101 to ZLS).

\section{Compliance with Ethical Standards}

Conflict of interest The authors declare that they have no conflict of interest.

Animal and Human Rights Statement All procedures performed in studies involving human participants were in accordance with the ethical standards of the Ethical Review Committee of Renmin Hospital of Wuhan University and with the 1964 Helsinki Declaration and its later amendments or comparable ethical standards. Informed consent was obtained from all participants enrolled in the study.

\section{References}

China Center for Disease Control and Prevention (China CDC) (2020) http://m.news.cctv.com/2020/01/09/ARTI9Vp9L ra4Tvltz3r7es96200109.shtml. Accessed 9 Jan 2020

Huang CB, Wang Q, Xie GQ, Liu AH, Lai B, Chen YJ, Cheng YJ, Xu H, Han DM (2004) Immunological characteristics of 1291 cases of severe acute respiratory syndrome in Beijing. Zhonghua Nei Ke Za Zhi 43:406-409 (in Chinese)

Kikkert M (2020) Innate immune evasion by human respiratory RNA viruses. J Innate Immun 12:4-20

National Health Commission of the People's Republic of China (2007) National surveillance, investigation and management plan of unexplained pneumonia cases. 2007 (Code 158) http:// www.nhc.gov.cn/bgt/pw10708/200708/4455f46a2f5e4908a8561 c079ecbcf0e.shtml. Accessed 20 Jan 2020

Seillet C, Belz GT, Huntington ND (2016) Development, homeostasis, and heterogeneity of NK cells and ILC1. Curr Top Microbiol Immunol 395:37-61

Wang N, Li SY, Yang XL, Huang HM, Zhang YJ, Guo H, Luo CM, Miller M, Zhu GJ, Chmura AA, Emily E, Zhou JH, Zhang YZ, 
Wang LF, Daszak P, Zhi ZL (2018) Serological evidence of bat SARS-related coronavirus infection in humans, China. Virol Sin 33:104-107

World Health Organization (WHO) (2020) Novel CoronavirusChina. https://www.who.int/csr/don/12-january-2020-novel-coro navirus-china/en/. Accessed 12 Jan 2020
Wuhan Municipal Health Commission (WMHC) (2020) http://wjw. wuhan.gov.cn/front/web/showDetail/2020012009077. Accessed 20 Jan 2020

Zhang J, Feng X, Liu S, Dai W, He Z, Dong Q, Song S, Liu Z, Yao J (2003) The study of B lymphocyte and NK cell in Severe Acute Respiratory Syndrome (SARS) patients. Chin J Immunol 19:378-380 (in Chinese) 